\title{
EFFECT OF VITAMIN E ON THE BLOOD-BRAIN BARRIER PERMEABILITY IN AGED RATS WITH PTZ-INDUCED CONVULSIONS
}

\author{
Received August 12, 2010.
}

\begin{abstract}
The effect of vitamin E on the blood-brain barrier (BBB) permeability was studied under conditions of pentylenetetrazole (PTZ)-induced convulsions in aged (23-to 24-month-old) male albino rats; Evans Blue was used as a tracer. The BBB permeability was found to considerably increase in rats with PTZ-evoked seizures; the Evans Blue contents in the left and right hemispheres and cerebellum + brainstem region were significantly higher than those in the control. Vitamin E used in the dose of $70 \mathrm{mg} / \mathrm{kg}$ exerted practically no beneficial effect on the increased BBB permeability in rats with seizures, while a greater dose of vitamin E $(700 \mathrm{mg} / \mathrm{kg})$ exerted a significant protective effect, especially with respect to the cerebellum + brainstem regions $(P<0.01)$. The seizure-related rise in the arterial blood pressure was also smaller in the latter experimental group. Thus, our observations confirm the importance of the dose of vitamin $\mathrm{E}$ as a protective factor for the BBB permeability and demonstrate that the dose dependence of this antioxidant in aged animals differs from that in younger organisms.
\end{abstract}

Keywords: epilepsy, seizures, blood-brain barrier, permeability, pentylenetetrazole, vitamin $\mathbf{E}$, geriatric.

\section{INTRODUCTION}

Epilepsy is a disease characterized by recurrent epileptic seizure attacks induced by significantly transformed cerebral activity. It was found that the development of such attacks is related to the appearance of a great amount of reactive oxygen species (ROSs) within the brain [1]. The state of epileptic attacks allows the molecules of polar compounds, proteins, neurotransmitters, and other agents of large molecular weights to permeate much easier into the brain because of demolishing of the blood-brain barrier (BBB) [2, 3]. Additionally, membrane phospholipids release arachidonic acid due to increased oxygen consumption during the attacks [4]. Production of free radicals increases under such conditions, in

\footnotetext{
${ }^{1}$ Halic University School of Health Sciences, Halic University, Istanbul, Turkey.

${ }^{2}$ Faculty of Medicine, Yeditepe University, Istanbul, Turkey.

${ }^{3}$ Istanbul Faculty of Medicine, Istanbul University, Istanbul, Turkey. Correspondence should be addressed to Hatice Yorulmaz (e-mail: haticeyorulmaz@halic.edu.tr).
}

particular, due to metabolization of arachidonic acid by cyclooxygenase. [5]. Free radicals can play the role of a powerful effector causing an increment in the BBB permeability; this can result in the creation of insults in the cerebral vascular endothelium $[6,7]$.

Biological effects of free radicals are controlled in vivo by a number of antioxidants, such as vitamins $\mathrm{E}, \mathrm{C}$, and $\mathrm{A}$ and glutathione [8,9]. Vitamin $\mathrm{E}$ is one of the most important chain-breaking antioxidants; it provides oxidative phosphorylation to continue (by preventing accumulation of high-energy phosphates in the mitochondria) and protects cell membranes against oxidative insult by regulating production of free radicals $[10,11]$.

In our studies, we found that vitamin E exerts a protective effect on the BBB in the course of epileptiform attacks created by introduction of pentylenetetrazole (PTZ) in young and adult rats [12]. However, the effect of vitamin $\mathrm{E}$ on the BBB permeability under conditions of convulsions constituted in aged organisms is not clear. In this study, we intended to examine the effect of vitamin $\mathrm{E}$ on the BBB permeability in the case of PTZ-induced convulsions in aged animals and the dose dependence of this effect. 


\section{METHODS}

The experimental procedure was in accordance with the Helsinki Declaration (2004). Forty aged (23- to 24-month-old) Wistar albino rats were used in the experiments. The animals were divided into four groups: group 1 (control), group 2 (animals with PTZinduced convulsions, PTZ group), and groups 3 and 4 (rats manifesting such PTZ-evoked convulsions and treated with vitamin $E$ in doses 70 and $700 \mathrm{mg} / \mathrm{kg}$, groups $\mathrm{PTZ}+\mathrm{E} 70$ and $\mathrm{PTZ}+700$, respectively). Each group consisted of 10 animals.

Cannulations of the femoral artery and vein were performed in animals under ether anesthesia. The blood pressure was measured in the above artery. The BBB permeability was characterized using an Evans Blue tracer ( $4 \mathrm{ml} / \mathrm{kg}$, i.v.). Pentylenetetrazole was i.v. injected in the dose of $100 \mathrm{mg} / \mathrm{kg}$ into rats of groups 2 to 4 , in order to induce convulsions after Evans Blue was given. Vitamin E was i.p. injected $30 \mathrm{~min}$ before Evans Blue injection in the above-mentioned doses (70 and $700 \mathrm{mg} / \mathrm{kg}$ ) in rats of groups 3 and 4 . The seizure attacks were monitored for $20 \mathrm{~min}$. Generalized convulsions characterized by tonic/clonic contractions of the limb and trunk muscles were observed in all animals.

The brains of the rats were elutriated by perfusion with $0.9 \% \mathrm{NaCl}$ solution via the left ventricle $25 \mathrm{~min}$ after Evans Blue injection. Then, the brains were dissected and separated into the left hemisphere, right hemisphere, and cerebellum + brainstem regions. Wet masses of the dissected samples were measured. Afterwards, each brain region was homogenized by placing in tubes with phosphate buffer $(2.5 \mathrm{ml})$. A $60 \%$ solution of trichloroacetic acid $(2.5 \mathrm{ml})$ was put in each tube after homogenizing; this procedure provided separation of Evans Blue from albumins by centrifuging with a vortex for $2 \mathrm{~min}$. After the vortex process, the tubes were kept at $4{ }^{\circ} \mathrm{C}$ for $30 \mathrm{~min}$ and centrifuged at $1,000 \mathrm{~g}$ for $30 \mathrm{~min}$. After centrifuging, the absorbance values were read spectrophotometrically at a $620 \mathrm{~nm}$ wavelength (after decanting supernatants to spectrophotometer tubes). The Evans Blue content values $(\mu \mathrm{g} / \mathrm{mg}$ tissue) were calculated for brain tissue samples using the Evans Blue absorbance-quantity regression equation and catenary via the obtained absorbance values. The statistical analysis was performed using ANOVA.

\section{RESULTS}

No differences were observed from the aspect of intensity of the tonic/clonic contraction phase during the epileptic attacks in groups 2-4 of rats injected with PTZ. The averaged values of blood pressure in all animal groups are shown in Fig. 1. As can be seen, no significant differences of the pre-seizure blood pressure values in groups 2-4 from those in group 1 (control) were observed. The development of PTZinduced convulsions resulted in a significant increase (by about 42\%) in the blood pressure in group 2 . Injection of vitamin $\mathrm{E}$ in a smaller dose (group 3) exerted no effect on the value of this shift. At the same time, in group 4 (PTZ + E700), a seizure-related rise in the blood pressure was also significant, as compared with the control, but noticeably less intense (by about $32 \%$ ) than that in group 3.

In control animals (group 1), the mean Evans Blue concentrations in the left and right hemispheres and in the cerebellum + brainstem regions were found to be $0.288 \pm 0.067,0.295 \pm 0.076$, and $0.368 \pm 0.078$ $(\mathrm{M} \pm$ s.d. $) \mu \mathrm{g} / \mathrm{mg}$ tissue, respectively. The corresponding values in group 2 after the development of PTZ-induced seizures were noticeably higher $(0.521 \pm 0.158,0.404 \pm$ \pm 0.045 , and $0.879 \pm 0.232 \mu \mathrm{g} / \mathrm{mg}$ tissue, i.e., the

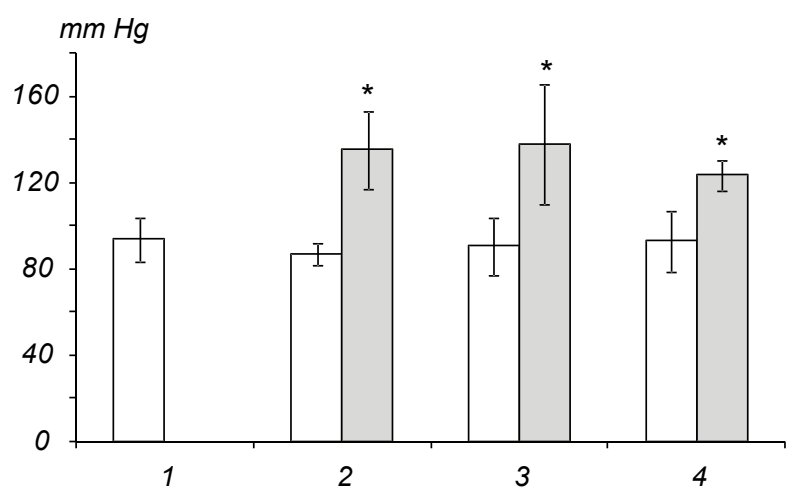

Fig 1. Mean values of the arterial blood pressure $(\mathrm{mm} \mathrm{Hg})$ in groups 1-4 of experimental rats. 1) Control group, 2) animal group with pentylenetetrazole (PTZ)-induced convulsions, 3 and 4) groups of rats with such seizures treated with vitamin $\mathrm{E}$ in doses of 70 (3) and $700(4) \mathrm{mg} / \mathrm{kg}$. In $2-4$, open and filled columns correspond to the blood pressure values measured before PTZ injections and to those measured within the seizure period, respectively. Means \pm s.d. are shown. Asterisks show cases of a significant difference from control $(P<0.05)$.

Р и с. 1. Середні значення артеріального кров'яного тиску в групах 1-4 (1-4) експериментальних щурів. 


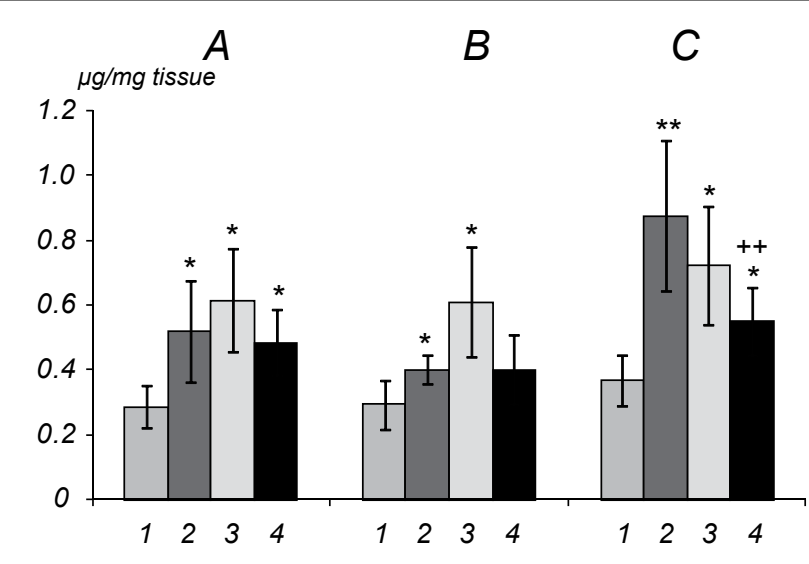

Fig. 2. Contents of the tracer (Evans Blue, $\mu \mathrm{g} / \mathrm{mg}$ tissue) in samples of the left brain hemisphere, right hemisphere, and cerebellum + + brainstem regions (A-C, respectively) in groups 1-4 of experimental rats. Intragroup means \pm s.d. are shown. Designations of animal groups are the same as in Fig. 1. One and two asterisks show cases of significant differences $(P<0.05$ and $P<0.01$, respectively) from the control group 1; two crosses show a significant difference $(P<0.01)$ from the value in group 2 (PTZ).

Р и с. 2. Вміст трасера (Еванса блакитного, мкг/мг тканини) у зразках лівої та правої мозкових півкуль та ділянки мозочка й стовбура мозку ( $A-C$ відповідно) у групах експериментальних тварин 1-4 (1-4).

increments were 81,37 , and $128 \%$, respectively $(P<0.05$ or $P<0.01$; Fig. 2$)$. These shifts were indicative of a significant increase in the BBB permeability in the course of PTZ-induced convulsions.

When aged rats with PTZ-induced seizure activity were treated with vitamin $\mathrm{E}$ in the smaller dose used (70 mg/kg; PTZ + E70 group), the mean Evans Blue concentrations in the above-mentioned cerebral regions were the following: $0.618 \pm 0.159$ and $0.611 \pm$ $\pm 0.171 \mu \mathrm{g} / \mathrm{mg}$ tissue in the left and right hemisphere and $0.713 \pm 0.183 \mu \mathrm{g} / \mathrm{mg}$ in the cerebellum + brainstem (Fig. 2). Thus, vitamin E applied in the above dose exerted practically no beneficial effect on the increased BBB permeability. The Evans Blue contents in the hemispheres were even somewhat greater than those in group 2. The content of the dye in the cerebellum + + brainstem was mildly (by $18 \%$ ) smaller than the respective value in group 2 , but the difference was insignificant $(P>0.05)$.

In group 4 (rats with PTZ-induced convulsion activity treated with vitamin $\mathrm{E}$ in the greater dose, $700 \mathrm{mg} / \mathrm{kg}$ ), the amount of Evans Blue in the left hemisphere was insignificantly smaller $(P>0.05)$ than that in group 2 (PTZ), and this index in the right hemisphere was nearly the same as that in the latter group (with no vitamin E). At the same time, the mean concentration of the dye in the cerebellum + brainstem of group-4 rats $(0.511 \pm 0.105 \mu \mathrm{g} / \mathrm{mg})$ was $37 \%$ lower $(P<0.01)$ than the respective value in group 2 (Fig. 2).

Greater values of standard deviations of the Evans Blue contents in brain tissues of animals of groups $2-4$, as compared with the corresponding figures in the control group 1, should be, probably, especially mentioned. In other words, the individual variability of the state of the BBB in animals with PTZ-induced seizures (both treated and not treated with vitamin $\mathrm{E}$ ) was rather extensive.

\section{DISCUSSION}

Our experiments demonstrated that: $i$ ) vitamin $\mathrm{E}$ is capable, in principle, of exerting a protective effect on the disturbed BBB permeability in old animals with experimentally induced epileptiform seizure activity, and $i i)$ the respective effects in aged rats differ significantly from those in younger animals.

The BBB permeability was shown to considerably increase during epileptic seizure attacks $[2,13]$. As was suggested, increased production of ROSs represents one of the crucial factors providing greater $\mathrm{BBB}$ permeability values during an after such attacks [12, 14]. A protective effect of vitamin E, which is wellknown as an important antioxidant agent, in particular with respect to endothelial cells, was demonstrated in a few studies [12, 15].

A significant increment in the arachidonic acid concentration together with that for free fatty acids was observed in experiments with PTZ-induced seizure attacks [4]. Metabolization of arachidonic acid with the involvement of cyclooxygenase and lipooxigenase causes intensified free radical generation [5]. Free radicals primarily start lipid peroxidation by reacting with unsaturated fatty acids in cell and organelle membranes [8]. Lipid peroxidation in the cerebral endothelial cell membranes is, probably, one of the main reasons for an increment in the BBB permeability $[6,7]$. The antioxidants, such as vitamins $\mathrm{A}, \mathrm{C}$, and (especially) E were shown to exert a protective effect on the BBB during epileptic attacks $[12,15,17]$. Vitamin E inactivates lipid peroxyl, superoxides, and other reactive species $[10,18]$. The most important cellular function of vitamin $\mathrm{E}$ is to protect cell membranes by inhibiting peroxidation of unsaturated fatty acids [19]. 
Vitamin E was shown to decrease the intensity of acute PTZ-sourced attacks in rats [20]. The levels of this vitamin in the blood plasma of children suffering from seizures were found to be lower than the respective values in control children of the same age [21]. Furthermore, an anti-attack effect of vitamin E was observed under experimental conditions, such as ferrous chloride model, hyperbaric oxygen model, kindling, and PTZ-evoked seizure activity $[20,22,23]$.

In our study, a sufficiently high dose of vitamin $\mathrm{E}$ demonstrated a clear protective effect against seizurerelated increase in the BBB permeability in old rats; this was especially considerable with respect to the cerebellum + brainstem regions of experimental animals. This observation contradicts results of some other studies were no protective effect of vitamin $\mathrm{E}$ on epileptic attacks created by PTZ and other chemical convulsants was found $[24,25]$. These contradictions are probably related to the fact that antioxidants manifest dissimilar anticonvulsant effects depending on the type of the convulsant or subeffective doses. Vitamin E administered in 300 or $500 \mathrm{mg} / \mathrm{kg}$ doses was shown to moderate the intensity of penicillin-sourced epileptiform activity in rats [26]. As was mentioned above, we found that this vitamin demonstrated a protective effect against seizure-related disorders of the BBB permeability in young and adult rats, and the $70 \mathrm{mg} / \mathrm{kg}$ dose was effective [12]. At the same time, it is well-known that there are noticeable age-dependent modifications of the epileptic and epileptiform activity [27]. The threshold value for the attacks created by PTZ introductions is higher in old animals, durations of generalized attacks are longer in this age group than in adults, and old animals are distinguished by a higher relapse ratio [28, 29]. In this our study, we found that the $70 \mathrm{mg} / \mathrm{kg}$ dose of vitamin E exerts practically no protective effect on the BBB under conditions of PTZinduced seizures in aged rats; such an effect appears only in the case of a much higher dose.

Alterations in the neuromodulatory systems depending on aging constitute the most probable reason for these dissimilarities. As was shown, these systems regulate in vivo the epileptiform activity and significantly influence the relapse severity, sensitivity, and prevalence $[30,31]$. Considerable modifications of synaptic connections, electrotonic coupling, features of receptors and channels, numbers and functions of specific-type neurons within neuronal networks develop due to aging [32-37]. Besides this, it was reported that age-dependent alterations also develop in the sodium/potassium equilibrium and extracellular volume, and these alterations noticeably affect neuronal synchronization and excitability [38-41]. Thus, much higher doses of vitamin $\mathrm{E}$ are needed to provide its protective effect against the increased permeability of the BBB during epileptic attacks in old organism.

The fact that Evans Blue contents in the hemispheres of rats in the PTZ + E70 group 3 were found to be not lower but even somewhat higher than the respective figures in group 2 (PTZ) may have two explanations. First, this can result from an occasional deviation mostly related to a high dispersion of this index in all PTZ groups. Another interpretation, however, should also be taken into account. Vitamin E, probably, cannot be considered an "absolute" antioxidant. There are indications that this vitamin is a redox reagent that can, under certain conditions, function as a prooxidant [42-45]. Thus, in some cases it probably can somewhat increase the disturbed BBB permeability.

\section{Х. Йорулмаз ${ }^{1}$, Ф. Бурку Секер², Б. Озтаз ${ }^{3}$}

\section{ВПЛИВ ВІТАМІНУ Е НА ПРОНИКНІСТЬ ГЕМАТО-

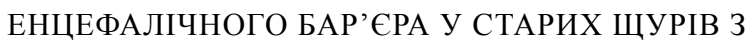 ПЕНТИЛЕНТЕТРАЗОЛІНДУКОВАНИМИ СУДОМАМИ}

\footnotetext{
${ }^{1}$ Школа охорони здоров'я Халік, Університет Халік, Стамбул (Туреччина).

${ }^{2}$ Університет Йедітепе, Стамбул (Туреччина).

${ }^{3}$ Стамбульський університет (Туреччина).

P е 3 ю м е
}

На старих (вік 23-24 місяці) самцях білих щурів досліджували вплив вітаміну Е на розлади проникності гематоенцефалічного бар'єра (ГЕБ), пов'язані 3 розвитком судомної активності, котра була індукована введенням пентилентетразолу (ПТЗ); як трасер використовували барвник Еванс блакитний. У тварин із ПТЗ-викликаними судомами проникність ГЕБ значно збільшувалася; вміст барвника в тканинах лівої та правої мозкових півкуль, мозочка та стовбура мозку вірогідно перевищував відповідні значення в контролі. Вітамін Е в дозі 70 мг/кг практично не справляв позитивного впливу на збільшену проникність ГЕБ у тварин із судомною активністю. Застосування ж вітаміну Е в більших дозах (700 мг/кг) забезпечувало істотний протективний ефект, особливо щодо зразків тканин мозочка та стовбура мозку $(P<0.01)$. Підвищення артеріального кров'яного тиску, пов'язане з розвитком судом, в останній з експериментальних серій було помірнішим, ніж у двох інших серіях. Отже, наші спостереження підтверджують важливість дозування вітаміну Е як протективного фактора щодо проникності ГЕБ та вказують на те, що залежність від 
дози цього вітаміну, використовуваного як антиоксидант, у старих тварин істотно відрізняється від такої у молодших організмів.

\section{REFERENCES}

1. R. Sridharan, "Epidemiology of epilepsy," Current Sci., 82, 664-670 (2002).

2. C. Nitsch and I. Klatzo, "Regional patterns of blood-brain barrier breakdown during epileptiform seizures induced by various convulsive agents," J. Neurol. Sci., 59, 305-322 (1983).

3. C. K. Petito, J. A. Schaefer, and F. Plum, "Ultrastructural characteristics of the brain blood-brain barrier in experimental seizures," Brain Res., 127, 251-267 (1977).

4. M. Ingvar, B. Söderfeld, J. B. K. Folbergova, et al., "Metabolic, circulatory and structural alterations in the rat brain induced by sustained pentylenetetrazole seizures," Epilepsia, 25, 191204 (1984).

5. P. K. Chan and R. A. Fishman, "The role of arachidonic acid in vasogenic brain edema," Fed. Proc., 43, 210-213 (1984).

6. L. L. Dugan and D. W. Choi, "Excitotoxicity, free radicals, and cell membrane changes," Ann. Neurol., 35, 17-21 (1994).

7. K. Ikeda, T. Nagashima, S. Wu, et al., "The role of calcium ion in anoxial reoxygenation damage of cultured brain capillary endothelial cells," Acta Neurochir., 70, 4-7 (1997).

8. B. Halliwell and J. M. C. Gutteridge, "The antioxidants of human extracellular Xuids," Arch. Biochem. Biophys., 280, 1-8 (1990).

9. B. Halliwell, "Lipid peroxidation, oxygen radicals, cell damage, and antioxidant therapy," Lancet, 23, 1396-1398 (1984).

10. C. Behl, "Vitamin E and other antioxidants in neuroprotection," Int. J. Vitam. Nutr. Res., 69, 213-219 (1999).

11. M. Koteghawa, M. Sugiyama, T. Shoji, et al., "Effect of $\alpha$-tocopherol on high energy phosphate metabolite levels in rat heart by P-NMR using a 20-LangendoV perfusion technique," J. Mol. Cell Cardiol., 25, 1067-1074 (1993).

12. B. Oztas, S. Akgul, and F. B. Seker, "Gender difference in the influence of antioxidants on the blood-brain barrier permeability during pentylenetetrazol-induced seizures in hyperthermic rat pups," Biol. Trace Elem. Res., 118, 77-83 (2007).

13. P. van Eijsden, R. G. Notenboom, O. Wu, et al., "In vivo $1 \mathrm{H}$ magnetic resonance spectroscopy, T2-weighted and diffusionweighted MRI during lithium-pilocarpine-induced status epilepticus in the rat," Brain Res., 1030, 11-18 (2004).

14. T. G. Bolwig, "Implications of the blood-brain barrier and Its manipulation," in: Epileptic Seizures and the Blood-Brain Barrier, E. A Neuwelt (ed.), Plenum Med. Book Comp., New York (1989), pp. 567-574.

15. W. M. Armstead, R. Mirro, C. W. Lefler, et al., "Cerebral superoxide anion generation during seizures in newborn pigs," J. Cerebr. Blood Flow Metab., 9, 175-179 (1989).

16. O. M. Schneider, F. A. Flavia, L. F. Freire Royes, et al., "Ascorbate modulates PTZ inuced convulsions biphasically," Neuroscience, 128, 721-728 (2004).

17. K. Sudha, A. V. Rao, and A. Rao, "Oxidative stress and antioxidants in epilepsy," Clin. Chim. Acta, 303, 19-24 (2001).
18. R. Brigelius-Flohe and M. G. Traber, "Vitamin E: function and metabolism," FASEB J., 13, 1145-1155 (1999).

19. R. J. Sokol, M. A. Guggenheim, S. T. Iannaccone, et al., "Improved neurologic function after long term correction of vitamin E deficiency in children with chronic cholestasis," New Engl. J. Med., 313, 1580-1586 (1985).

20. C. Rauca, I. Wiswedel, R. Zerbe, et al., "The role of superoxide dismutase and alpha-tocopherol in the development of seizures and kindling induced by pentylenetetrazol-influence of the radical scavenger alpha-phenyl-N-tert-butyl nitrone," Brain Res., 1009, 203-212 (2004).

21. A. O. Ogunmekan, "Vitamin E deficiency and seizures in animals and man," J. Can. Sci. Neurol., 6, 43-45 (1979).

22. S. A. Jerrett, D. Jefferson, and C. E. Mengel, "Seizure $\mathrm{H}_{2} \mathrm{O}_{2}$ and lipid peroxidase in brain during exposure to oxygen under high pressure," Aeroesp. Med., 44, 40-44 (1973).

23. S. 1. Levy, W. M. Burnham, A. Bishai, et al., "An evaluation of the anticonvulsant effects of vitamin E," Epilepsy Res., 6, 12-17 (1990).

24. R. C. Milatovic, R.C. Gupta, and W.-D. Dettbarn, "Involvement of nitric oxide in kainic acid-induced excitotoxicity in rat brain," Brain Res., 957, 330-337 (2002).

25. P. V. Monahan and H. A. Yamamoto, "Preventive effect of melatonin against brain mitochondria DNA damage, lipid peroxidation and seizures induced by kainic acid," Toxicol. Lett., 129, 99-105 (2002).

26. M. Ayyildiz, M. Yildirim, and E. Agar, "The effects of vitamin E on penicillin-induced epileptiform activity in rats," Exp. Brain Res., 174, 109-113 (2006).

27. I. E. Leppik, "Epilepsy in the elderly," Rev. Neurol., 11, 4455 (2004).

28. S. Chiba, Y. Muneoka, S. Kamata, et al., "The amygdaloid kindling in developing, adult and aged rats," Jpn. J. Psychiat. Neurol., 46, 516-551 (1992).

29. M. Nokubo and K. Kitani, "Age-dependent decrease in the lethal threshold of pentylenetetrazole in mice," Life Sci., 43, 41-47 (1988).

30. G. J. Klapstein and W. F. Colmers, "Neuropeptide Y suppresses epileptiform activity in rat hippocampus in vitro," J. Neurophysiol., 78, 1651-1661 (1997).

31. M. Rubinstein, C. Cepeda, R. S. Hurst, et al., "Dopamine D4 receptor-deficient mice display cortical hyperexcitability," $J$. Neurosci., 21, 3756-3763 (2001).

32. C. A. Barnes, G. Rao, and B. L. McNaughton, "Increased electrotonic coupling in aged rat hippocampus: a possible mechanism for cellular excitability changes," J. Comp. Neurol., 259, 549-558 (1987).

33. C. L. Cadacio, T. A. Milner, M. Gallagher, et al., "Hilar neuropeptide $\mathrm{Y}$ interneuron loss in the aged rat hippocampal formation," Exp. Neurol., 183, 147-158 (2003).

34. A. Gutierrez, Z. U. Khan, D. Ruano, et al., "Aging-related subunit expression changes of the GABAA receptor in the rat hippocampus," Neuroscience, 74, 341-348 (1996).

35. P. R. Rapp, E. C. Stack, and M. Gallagher, "Morphometric studies of the aged hippocampus: I. Volumetric analysis in behaviorally characterized rats," J. Comp. Neurol., 403, 45970 (1999).

36. A. K. Shetty and D. A. Turner, "Hippocampal interneurons expressing glutamic acid decarboxylase and calcium-binding proteins decrease with aging in Fischer 344 rats," J. Comp. Neurol., 394, 252-269 (1998).

37. T. D. Smith, M. M. Adams, M. Gallagher, et al., "Circuit-specific alterations in hippocampal synaptophysin immunoreactivity 
predict spatial learning impairment in aged rats," J. Neurosci., 20, 6587-6593 (2000).

38. F. E. Dudek, P. R. Patrylo, and J. P. Wuarin, "Mechanisms of neuronal synchronization during epileptiform activity," $A d v$. Neurol., 79, 699-708 (1999).

39. N. M. Porter, O. Thibault, V. Thibault, et al., "Calcium channel density and hippocampal cell death with age in long-term culture," J. Neurosci., 17, 5629-5639 (1997).

40. E. L. Roberts Jr. and Z. C. Feng, "Influence of age on the clearance of $\mathrm{K}^{+}$from the extracellular space of rat hippocampal slices," Brain Res., 708, 16-20 (1996).

41. E. Sykova., T. Mazel, and Z. Simonova, "Diffusion constraints and neuron-glia interaction during aging," Exp. Gerontol., 33, 837-851 (1998).

42. V. S. Bowry and R. Stocker, "Tocopherol-mediated peroxidation: the prooxidant effect of vitamin $\mathrm{E}$ on the radical initiated oxidation of human low-density lipoprotein", J. Am. Chem. Soc., 115, 6029-6044 (1993).

43. K. U. Ingold, V. W. Bowry, R. Stocker, and C. Walling, "Autoxidation of lipids and antioxidation by $\alpha$-tocopherol in homogeneous solutions and in aqueous dispersions of lipids," Proc. Natl. Acad. Sci. USA, 90, 45-49 (1993).

44. J. Neuzil, S. R. Thomas, and R. Stocker, "Requirement for, promotion, or inhibition by $\alpha$-tocopherol of radical-induced initiation of plasma lipoprotein lipid peroxidation," Free Radic. Biol. Med., 22, 57-71 (1997).

45. M. S. Winterbone, M. J. Sampson, S. Saha, et al., "Pro-oxidant effect of alpha-tocopherol in patients with type 2 diabetes after an oral glucose tolerance test - a randomised controlled trial," Cardiovasc Diabetol., 22, 6-8 (2007). 